BMC

Complementary \& Alternative Medicine

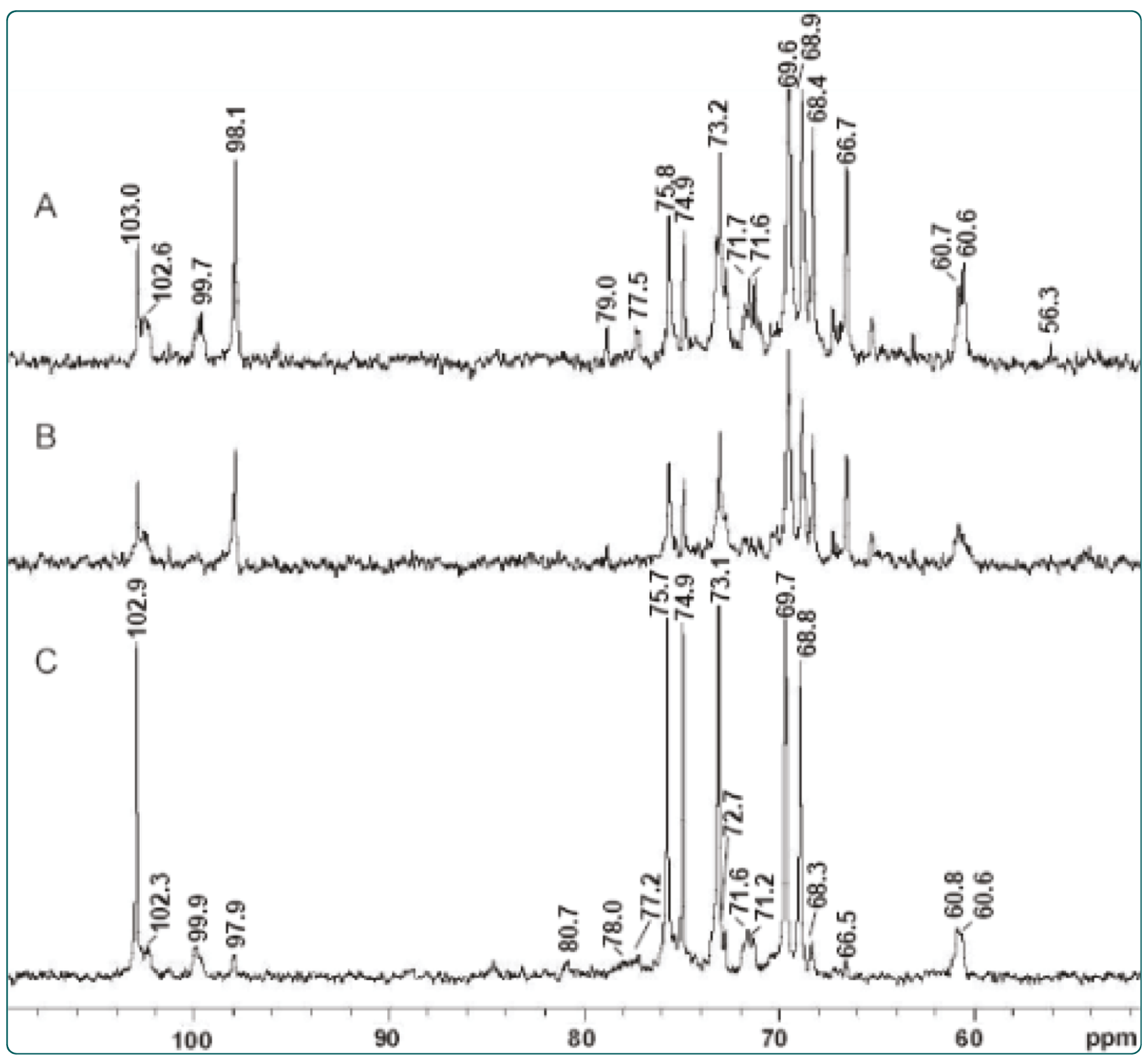

Polysaccharides from Agaricus bisporus and Agaricus brasiliensis show similarities in their structures and their immunomodulatory effects on human monocytic THP-1 cells

Smiderle et al. 


\title{
Polysaccharides from Agaricus bisporus and Agaricus brasiliensis show similarities in their structures and their immunomodulatory effects on human monocytic THP-1 cells
}

Fhernanda R Smiderle ${ }^{2}$, Andrea C Ruthes ${ }^{2}$, Jeroen van Arkel', Wasaporn Chanput ${ }^{3}$, Marcello lacomini ${ }^{2}$, Harry J Wichers ${ }^{3}$ and Leo JLD Van Griensven ${ }^{1 *}$

\begin{abstract}
Background: Mushroom polysaccharides have traditionally been used for the prevention and treatment of a multitude of disorders like infectious illnesses, cancers and various autoimmune diseases. Crude mushroom extracts have been tested without detailed chemical analyses of its polysaccharide content. For the present study we decided to chemically determine the carbohydrate composition of semi-purified extracts from 2 closely related and well known basidiomycete species, i.e. Agaricus bisporus and A. brasiliensis and to study their effects on the innate immune system, in particular on the in vitro induction of pro-inflammatory cytokines, using THP-1 cells.

Methods: Mushroom polysaccharide extracts were prepared by hot water extraction and precipitation with ethanol. Their composition was analyzed by GC-MS and NMR spectroscopy. PMA activated THP-1 cells were treated with the extracts under different conditions and the production of pro-inflammatory cytokines was evaluated by qPCR.

Results: Semi-purified polysaccharide extracts of A. bisporus and A. brasiliensis (= blazei) were found to contain $(1 \rightarrow 6),(1 \rightarrow 4)$-linked $\alpha$-glucan, $(1 \rightarrow 6)$-linked $\beta$-glucan, and mannogalactan. Their proportions were determined by integration of ${ }^{1} \mathrm{H}-\mathrm{NMR}$ signs, and were considerably different for the two species. A. brasiliensis showed a higher content of $\beta$-glucan, while $A$. bisporus presented mannogalactan as its main polysaccharide. The extracts induced a comparable increase of transcription of the pro-inflammatory cytokine genes IL-1 $\beta$ and TNF- $\alpha$ as well as of COX-2 in PMA differentiated THP-1 cells. Pro-inflammatory effects of bacterial LPS in this assay could be reduced significantly by the simultaneous addition of $A$. brasiliensis extract.

Conclusions: The polysaccharide preparations from the closely related species A. bisporus and A. brasiliensis show major differences in composition: A. bisporus shows high mannogalactan content whereas A. brasiliensis has mostly $\beta$-glucan. Semi-purified polysaccharide extracts from both Agaricus species stimulated the production of proinflammatory cytokines and enzymes, while the polysaccharide extract of A. brasiliensis reduced synthesis of these cytokines induced by LPS, suggesting programmable immunomodulation.
\end{abstract}

Keywords: Agaricus bisporus, A. brasiliensis, a-glucan, $\beta$-glucan, mannogalactan, immunomodulation

\footnotetext{
* Correspondence: leo.vangriensven@wur.nl

'Plant Research International, Wageningen University and Research,

Bornsesteeg 1, 6708 PD Wageningen, The Netherlands

Full list of author information is available at the end of the article
} 


\section{Background}

Mushroom polysaccharides have traditionally been used for the prevention and treatment of a multitude of disorders like infectious illnesses, cancers and various autoimmune diseases. Bioactive polysaccharides are recognized by membrane receptors in leukocytes and macrophages, leading to proliferation and differentiation of immune cells $[1,2]$. These activities are responsible for enhancing the innate and cell-mediated immune responses, and consequently, for the induction of antitumoral and bactericidal effects $[3,4]$.

Dendritic cells (DC's) and macrophages play important roles in many host reactions. They process antigen material and present it on their surface to other cells of the immune system. That is, they function as antigenpresenting cells to the $\mathrm{T}$ cells controlling immunity. Macrophages might behave both as pro-inflammatory cells to prevent e.g. infectious disease, as well as antiinflammatory cells with a reparatory effect, as in wound healing [5]. By binding to their receptors, the bioactive polysaccharides activate various immune pathways like phagocytosis, complement activity, and respiratory burst and also the production of cytokines such as tumor necrosis factor- $\alpha$ (TNF- $\alpha$ ), different kinds of interleukins (IL's) and enzymes as cyclooxygenase-2 (COX-2) $[6,7]$. All these effects collaborate to modulate cell differentiation and proliferation, enabling the host to defend itself against pathogens and tumors.

The monocytic THP-1 human myeloid leukemia cell line [8] expresses the Fc receptor and can be induced by phorbol 12-myristate 13-acetate (PMA) to differentiate into macrophage-like morphology [9]. Upon PMA treatment the suspension culture changes and cells become adherent to glass and plastics and show an increase in mitochondrial and lysosomal numbers and in cytoplasmic to nuclear ratio, as well as an altered differentiation dependent on cell surface markers in a pattern similar to monocyte-derived macrophages [10]. In addition they have a high absorption capacity for latex micro beads and express a cytokine profile that resembles macrophages.

Ganoderma lucidum polysaccharides have been found to induce monocytic THP-1 cells into dendritic cells [11] if added together with GM-CSF/IL-4, and recently it was published [12] that G. lucidum polysaccharides induced cytokine secretion and cell death in the same cell line. Also a heteromannan isolated from Morchella esculenta was able to activate the expression of NF- $\kappa \mathrm{B}$ in THP-1 cells [13].

Among the polysaccharides that are encountered in mushrooms and have been tested in vitro and in vivo there are $\alpha$-glucans, $\beta$-glucans, heterogalactans, heteroglucans, and others. The immunomodulatory effects are attributed mainly to $(1 \rightarrow 3)$ - $\beta$-glucans and $(1 \rightarrow 3)(1 \rightarrow 6)$ $\beta$-glucans $[14,15]$. Linear $(1 \rightarrow 6)-\beta$-glucans and $(1 \rightarrow 4)-\alpha$ glucans of $A$. brasiliensis were shown to present antitumoral activities [16]. Interestingly, Ito et al. (1997) [17] have reported that macrophage activation and an alteration of complement factor $\mathrm{C} 3$ is necessary for the induction of an anti-tumor effect when A. brasiliensis polysaccharides are used.

Heteropolysaccharides isolated from different basidiomycetes were also considered as bioactive polymers, showing a large diversity of structures and effects. Galactoglucomannan (L. edodes), xyloglucan (P. pulmonarius), and glucogalactan (G. lucidum) are examples of these molecules [1].

The range of extractions and isolation procedures used nowadays $[2,18]$ to separate carbohydrate contents from mushrooms, leads to different yields and compositions of bioactive materials. Usually the extracts obtained are not completely pure, retaining small amounts of proteins, phenolic components, and/ or other carbohydrates that can also influence the biological effects. It was observed that proteins, terpenoids, steroids, and fatty acids all can function as immunomodulators, respectively as cytotoxic, antitumor, antibactericidal, and antihypertension compounds [1].

Since the different components of a mushroom extract may act in synergy, careful studies have to be carried out to compare the activity of isolated compounds with those of crude mushroom extracts and whether whole mushrooms provide benefits that go beyond those achievable with isolated constituents. It remains therefore necessary to perform chemical analyses of the crude extracts to evaluate their components, and to compare these biological effects with the activities observed for the isolated agents.

For the present study we decided to chemically determine the carbohydrate composition of semi-purified extracts from 2 closely related and well known basidiomycete species, i.e. Agaricus bisporus and A. brasiliensis and to study their effects on the innate immune system, in particular on the in vitro induction of pro-inflammatory cytokines, using THP-1 cells.

\section{Methods}

\section{Cell culture}

The human monocytic cell line THP-1 (Cell Lines Service, Eppelheim, Germany) was grown in RPMI 1640 culture medium (Sigma, cat. R8758) supplemented with 10\% heat-treated newborn calf serum Sterile A (Gibco, cat. 161010-159) and $100 \mathrm{U} / \mathrm{mL}$ resp. $100 \mathrm{ug} / \mathrm{mL}$ penicillin/ streptomycin $(\mathrm{P} / \mathrm{S})$ (Sigma-Aldrich), at $37^{\circ} \mathrm{C}$ in $5 \% \mathrm{CO}_{2}$ in a humidified incubator. 


\section{Macrophage differentiation and stimulation}

The mature macrophage-like state was induced by treating THP-1 monocytes $(500,000$ cells $/ \mathrm{mL})$ for $48 \mathrm{~h}$ with 30 ng/mL phorbol 12-myristate 13-acetate (PMA; Sigma) in 24-wells polystyrene tissue culture plates (Costar) with $1 \mathrm{~mL}$ cell suspension in each well. The medium was then removed and replaced by fresh medium containing the different test samples.

\section{Gene expression kinetics by Real-Time PCR}

Total RNA was isolated by using RNeasy mini kit (Qiagen, USA) with a RNase-free DNase (Qiagen) treatment for 15 min according to the manufacturer's instructions. Complementary DNA (cDNA) was synthesized from isolated RNA with Taqman Reverse Transcription Reagent kit (Applied Biosystems, USA). Expression levels of each gene were measured in duplicate reactions, performed with the same cDNA pool, in the presence of the fluorescent dye (iQ SYBR Green Supermix) using an iCycler iQ instrument (Bio-Rad Laboratories). The experiments were performed in a $20 \mu \mathrm{L}$ reaction volume with specific primer pairs [19], and the conditions of real-time quantitative PCR were as follows: denaturation at $95^{\circ} \mathrm{C}$ for $3 \mathrm{~min}$ and amplification by cycling 40 times at $95^{\circ} \mathrm{C}$ for $10 \mathrm{~s}$ and $60^{\circ} \mathrm{C}$ for $30 \mathrm{~s}$. Glyceraldehyde-3-phosphate dehydrogenase (GAPDH) was chosen for normalisation. The PCR of all products were subjected to a melting curve analysis to verify the single amplification product. The relative messenger RNA (mRNA) expression were presented as described in Chanput et al. (2010) [19]: the values were expressed as fold change relative to the value at time point zero, calculated as $\Delta \Delta \mathrm{Ct}\left[\Delta \Delta \mathrm{Ct}=2^{\wedge}\left(\mathrm{Ct}_{\mathrm{GAPDH}}-\mathrm{Ct}_{\text {Sample }}\right)\right]$ [20]. All experiments were performed with the same amount of cells $\left(0.5 \times 10^{6}\right.$ per $\left.\mathrm{ml}\right)$ and the same quantity of RNA input. qPCR was performed twice on each sample, in duplicate.

\section{Mushroom extracts preparation}

The crude extracts from fruiting bodies of Agaricus bisporus (J.E. Lange) Imbach strain Sylvan A15, which is a commercial substrain of Horst U1 (ATCC 62462) and Agaricus brasiliensis Wasser et al. (syn. Agaricus blazei Murill) strain M7700, obtained from Innerlife B.V. (Venlo, The Netherlands) were prepared by hot water extraction as described before [21] and concentrated to $>35^{\circ}$ Brix for cold storage. Polysaccharides were semi-purified by repeated precipitation with two volumes of $96 \%$ ethanol. The precipitate was dissolved in water and then centrifuged at 12,000 rpm in an Eppendorf centrifuge to remove residual solids. The solution was three times frozen and thawed and the precipitate was centrifuged as before. The resulting pellet (HWP) and the soluble fraction (HWS) were lyophilized. Both fractions were tested on THP-1 cells.

\section{Analysis of monosaccharide composition by GC-MS}

Each polysaccharide fraction (1 mg) was hydrolyzed with $2 \mathrm{M}$ TFA at $100^{\circ} \mathrm{C}$ for $8 \mathrm{~h}$, followed by evaporation to dryness. The dried carbohydrate samples were dissolved in $0.5 \mathrm{~N} \mathrm{NH}_{4} \mathrm{OH}(100 \mu \mathrm{L})$, held at room temperature for 10-15 min in reinforced $4 \mathrm{ml}$ Pyrex tubes with Teflon lined screw caps. $\mathrm{NaBH}_{4}(1 \mathrm{mg})$ was added, and the solution was maintained at $100^{\circ} \mathrm{C}$ for $10 \mathrm{~min}$, in order to reduce aldoses to alditols [22]. The product was dried and excess $\mathrm{NaBH}_{4}$ was neutralized by the addition of acetic acid or $1 \mathrm{M}$ TFA $(100 \mu \mathrm{L})$, which was removed following the addition of methanol $(\times 2)$ under a $\mathrm{N}_{2}$ stream in a fume hood. Acetylation of the Me-alditols was performed in pyridine- $\mathrm{Ac}_{2} \mathrm{O}(200 \mu \mathrm{l} ; 1: 1, \mathrm{v} / \mathrm{v})$, heated for $30 \mathrm{~min}$ at $100^{\circ} \mathrm{C}$. The resulting alditol acetates were analyzed by GC-MS, and identified by their typical retention times and electron impact profiles. Gas liquid chromatography-mass spectrometry (GC-MS) was performed using a Varian (model 3300) gas chromatograph linked to a Finnigan Ion-Trap model 810 R-12 mass spectrometer, with $\mathrm{He}$ as carrier gas. A capillary column $\left(30 \mathrm{~m} \times 0.25 \mathrm{~mm}\right.$ i.d.) of DB-225, held at $50^{\circ} \mathrm{C}$ during injection and then programmed at $40^{\circ} \mathrm{C} / \mathrm{min}$ to $220^{\circ} \mathrm{C}$ or $210^{\circ} \mathrm{C}$ (constant temperature) was used for qualitative and quantitative analysis of alditol acetates and partially O-methylated alditol acetates, respectively [23].

\section{Analysis of monosaccharide composition by HPLC}

The samples were hydrolyzed with $2 \mathrm{M}$ TFA at $100^{\circ} \mathrm{C}$ overnight, followed by evaporation to dryness. The residual TFA was removed by two evaporation cycles with $0.5 \mathrm{~mL}$ of $\mathrm{MeOH}$, and the final residue was dissolved in $0.5 \mathrm{~mL}$ of $\mathrm{H}_{2} \mathrm{O}$.

After 100 fold dilution monosaccharides were determined using a Dionex HPLC system (Dionex Corp. Sunnyvale, Cal. USA) fitted with a Carbo Pac PA-1 column (4-250 mm), and a $25 \mu \mathrm{L}$ sample loop with $20 \mathrm{mM}$ $\mathrm{NaOH}$ isocratic solution $(1 \mathrm{~mL}$ min-1) as the mobile phase. An ED40 electrochemical detector fitted with a pulsed amperometric cell was used. Glucose and galactose were used as standards.

\section{Spectroscopy analysis}

Nuclear magnetic resonance (NMR) $\left({ }^{13} \mathrm{C}\right.$ and coupled ${ }^{1} \mathrm{H}$ (obs.), ${ }^{13} \mathrm{C}$ heteronuclear single quantum correlation (HSQC) spectra were obtained using a $400 \mathrm{MHz}$ Bruker model DRX Avance spectrometer incorporating Fourier transform, as described before in detail [24]. Samples were dissolved in $\mathrm{D}_{2} \mathrm{O}$ and examined at $70^{\circ} \mathrm{C}$. Chemical shifts are expressed in ppm $(\delta)$ relative to the resonance of $\mathrm{D}_{2} \mathrm{O}$ at $\delta 30.2\left({ }^{13} \mathrm{C}\right)$ and 2.22 $\left({ }^{1} \mathrm{H}\right)$. 
Determination of the phenolic content of the extracts

Folin assay was used for the phenolic determination of the extracts [25]. $100 \mu \mathrm{L}$ Folin's phenol reagent was added to each sample $(50 \mu \mathrm{L})$ and the solutions were mixed well. Then, $400 \mu \mathrm{L} \mathrm{Na} \mathrm{CO}_{3}$ was added to each mixture. The absorption of $200 \mu \mathrm{L}$ of each sample was measured at $590 \mathrm{~nm}$ in the SPECTRAFluor spectrophotometer. Gallic acid was used as a standard in concentrations ranging from 12.5 to $50 \mu \mathrm{g} / \mathrm{mL}$.

\section{Statistical Analysis}

The results are expressed as mean \pm standard deviation of duplicate cultures of two representative experiments. Statistical significance was determined using one-way analysis of variance (ANOVA) followed by Bonferroni's test. $\mathrm{P} \leq 0.05$ was considered statistically significant. The graphs were drawn and the statistical analyses were performed using GraphPad Prism version 5.01 for Windows (GraphPad Software, San Diego, CA, USA).

\section{Results}

\section{Chemical analysis of the extracts}

The semi-purified polysaccharide extracts were analyzed for phenol content as well as for their monosaccharide composition. The phenol components were measured by the Folin-Ciocalteau method based on the chemical reduction of the reagent [25], while the monosaccharide composition was analysed by HPLC. A. bisporus (ABS) and $A$. brasiliensis (ABL) extracts contained 0.96 and $0.78 \mu \mathrm{g}$ phenol per mg of dry matter, respectively. Wei et al. (2008) [26] had found $3.4 \%$ and $2.1 \%$ of phenol content in $A$. bisporus and $A$. brasiliensis, respectively. The latter authors observed that polysaccharides of A. brasiliensis and also a brown-colored polysaccharide/ phenol complex of $A$. bisporus were very active ROS generators. It has been published that polysaccharides are able to bind to polyphenols by intermolecular interactions [27], changing the molecular conformation of carbohydrates; therefore their presence should not be ignored.

The main monosaccharides of the samples and their respective proportions are given in Table 1 . The extract from $A$. bisporus presented mainly glucose, mannose, galactose, and methyl-galactose. The presence of methyl groups was confirmed by GC-MS.

Table 1 Monosaccharide composition of the extracts

\begin{tabular}{ccccccc}
\hline \multicolumn{7}{c}{ Monosaccharides (\%) } \\
\hline Sample & Glucose & Mannose & Galactose & Gal-Me & Fucose & Ribose \\
\hline ABS & 51.4 & 6.8 & 33.9 & 3.0 & 1.6 & 3.3 \\
ABSE & 43.0 & 10.3 & 36.6 & 3.3 & 2.0 & 4.8 \\
ABL & 66.7 & 4.9 & 23.1 & - & 5.6 & - \\
\hline
\end{tabular}

The samples were analyzed by HPLC. *Confirmed by GC-MS.
The ${ }^{13} \mathrm{C}$-NMR spectrum showed four signals in the anomeric region at $\delta 98.1,99.7,102.6$, and $103.0 \mathrm{ppm}$ (Figure 1a). The resolution and complexity of the signs indicates the presence of more than one polysaccharide in the sample. After treatment with $\alpha$-amylase from B. licheniformis $(250 \mathrm{U} / \mathrm{mL})$ for $2 \mathrm{~h}$ at $50^{\circ} \mathrm{C}$ and re-precipitation with ethanol, the remainder (ABSE) showed a reduction of the level of glucose when analysed by GCMS (Table 1). It can be seen in Figure $1 \mathrm{~b}$ that the signs at $\delta 99.7 \mathrm{ppm}$ and between $\delta 60.0$ and $80.0 \mathrm{ppm}$ do not appear in the spectrum anymore, showing clearly that there was a poorly branched $\alpha$-glucan present with a main chain $(1 \rightarrow 4)$-linked, which was degraded by the enzyme. The original signs at $\delta 98.1,102.6$, and 103.0 ppm were not reduced. The presence of an $\alpha$-glucan in A. bisporus had already been described previously [24]. These authors showed by NMR experiments and methylation analysis that the $\alpha$-glucan was composed of a $(1 \rightarrow 4)$-linked main chain, substituted at O-6 by single units of $\alpha$-glucose in the proportion 1:8. Normally, $\beta$-glucans are isolated from mushrooms [6]. We distinguished six signals in the ${ }^{13} \mathrm{C}$-NMR spectrum at $\delta 103.0 ; 75.8$; $74.9 ; 73.2 ; 69.6$; $68.4 \mathrm{ppm}$, typical from $\beta$-glucan $(1 \rightarrow 6)$ linked, which was confirmed by the inversion of the sign at $\delta 68.4$ in the DEPT experiment (data not shown). Several other low intensity signals were observed for this polysaccharide fraction and seem to be related to a polysaccharide composed mainly of galactose, as already observed for other basidiomycetes such as Pleurotus ostreatus [28], P. pulmonarius [29], P. eryngii and $P$. ostreatoroseus [30]. The latter authors isolated an $\alpha$-galactan, while the previous ones described a mannogalactan from Pleurotus genus. In our study we found $10 \%$ of mannose in the ABS extract, and the spectra showed more complexity, giving a strong indication that a similar mannogalactan, as the one described by Jakovljevic et al. (1998) [28] and Smiderle et al. (2008) [29] is presented also in $A$. bisporus. Both authors isolated a polysaccharide with a main chain composed of $(1 \rightarrow 6)$ $\alpha$-galactose substituted at $\mathrm{O}-2$ by $\beta$-mannose units. Interestingly, galactomannan and terminal mannose have been found to bind to mannose receptors in human phagocytic cells and exert immunomodulatory effects [13,31]. Furthermore, this heteropolymer contains natural methyl groups indicated by the sign at $\delta 56.3 \mathrm{ppm}$, and confirmed by GC-MS analysis showing the presence of 3-Omethyl-galactose. We decided to perform ${ }^{1} \mathrm{H}-\mathrm{NMR}$ and HSQC experiments to evaluate the proportion of each polysaccharide present in ABS extract. It was possible to integrate four main signals from the ${ }^{1} \mathrm{H}$-NMR spectrum (data not shown) based on HSQC anomeric region (Figure $2 \mathrm{a})$, and determine the proportion of $\alpha$-glucan (20.4\%), $\beta$-glucan (23.7\%), and mannogalactan (55.8\%) in the extract (Table 2). These two samples partially purified 


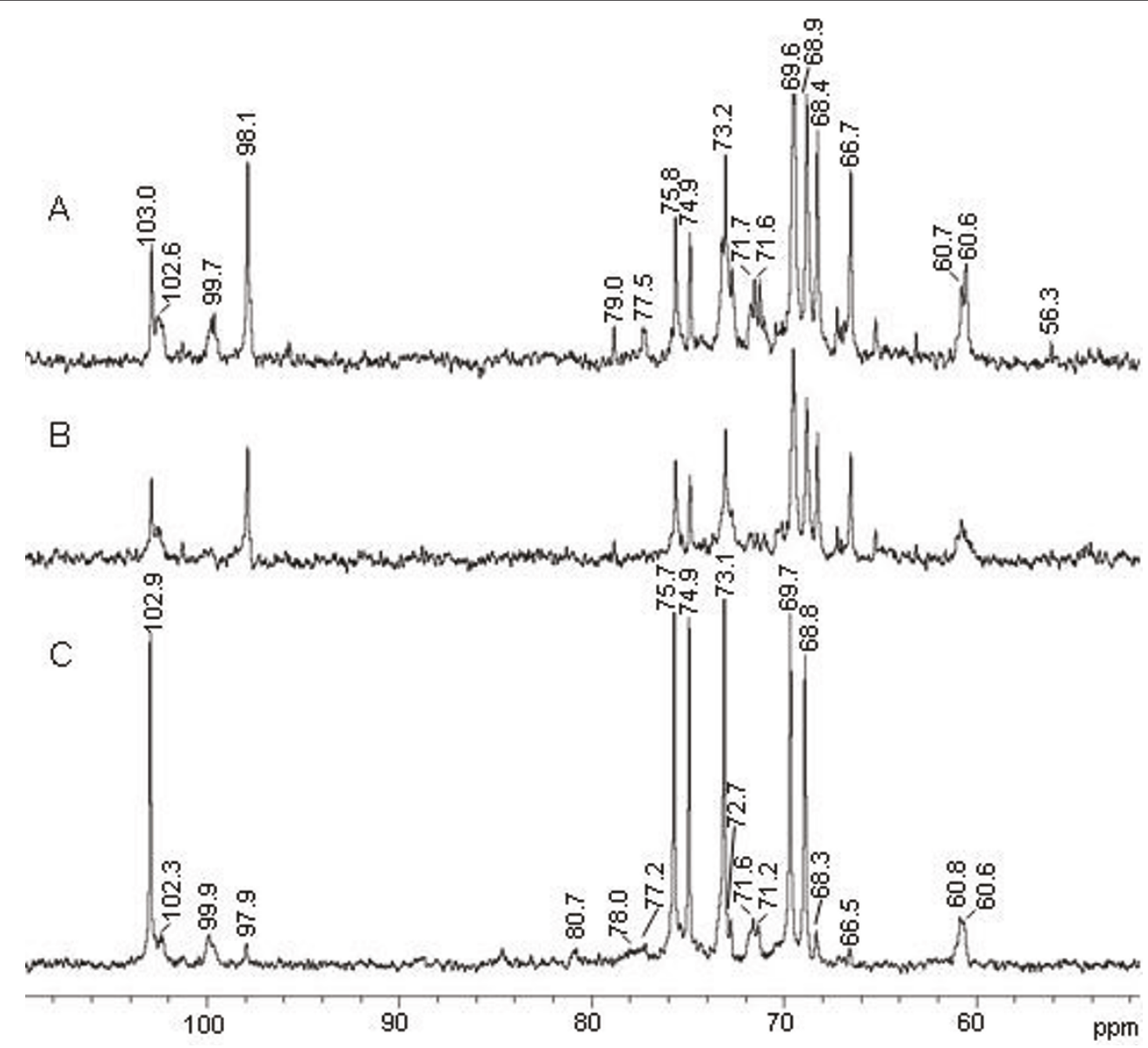

Figure $1{ }^{13} \mathrm{C}$-NMR spectra of $A$. bisporus extract, and $A$. brasiliensis extracts. ${ }^{13} \mathrm{C}-\mathrm{NMR}$ spectra of $A$. bisporus extract (ABS) before (A) and after (B) $\alpha$-amylase treatment (ABSE), and A. blazei extract (ABL) (C) in $\mathrm{D}_{2} \mathrm{O}$ at $50^{\circ} \mathrm{C}$ (chemical shifts are expressed in $\delta$ ppm).

polysaccharides (ABS) and the same after $\alpha$-amylase treatment and re-precipitation (ABSE) were tested for their immuno activity properties in THP-1 cells.

The polysaccharide fraction prepared of $A$. brasiliensis showed similar monosaccharide composition as the fraction observed for A. bisporus (Table 1), although the proportion of glucose was higher. The ${ }^{13} \mathrm{C}-\mathrm{NMR}$ spectrum (Figure 1c) also showed similarities with the other species regarding the presence of the signals, especially in the anomeric region. The high intensity signs arise from the linear $(1 \rightarrow 6)$ - $\beta$-glucan $(\delta$ 102.9; 75.7; 74.9; 73.1; 69.7; 68.8 ppm), as already described for $A$. brasiliensis [32]. The inversion of the sign at $\delta 68.8 \mathrm{ppm}$ in the ${ }^{13} \mathrm{C}$-NMR DEPT spectrum proved the O-6 linkage (data not shown). Minor signs at $\delta 97.9$ and $102.3 \mathrm{ppm}$ confirmed the presence of the mannogalactan that we found for A. bisporus. Although some authors commented about the presence of galactose and mannose in A. brasiliensis, this heteropolymer was not well-characterized yet for these two species [16]. The $(1 \rightarrow 4)$-linked $\alpha$-glucan is present in higher amounts than in A. bisporus, even though the signal was not so evident at $\delta 99.9 \mathrm{ppm}$. The high concentration and solubility of the $\beta$-glucan evidences its signs in the spectrum, and reduces the resolution of the other molecules' signals. The $\alpha$-glucan was also observed for $A$. brasiliensis and described by Gonzaga et al. (2005) [18]. By analyses of HSQC (Figure 2b) and integration of the areas in ${ }^{1} \mathrm{H}-\mathrm{NMR}$ spectrum (data not shown) it was possible to determine the proportion of each polysaccharide in the extract: $\alpha$-glucan (25.7\%), $\beta$-glucan (49.1\%), and mannogalactan (25.2\%) (Table 2). This extract was also tested on THP-1 cells. The protein content of both mushroom extracts was low since the NMR spectra showed no or few N-H signals (data not shown).

Gene expression for inflammation-related cytokines and enzymes of THP-1 macrophages stimulated with extracts The extracts were added to THP-1 macrophages (after differentiation with PMA) at $250 \mu \mathrm{g} / \mathrm{mL}$. Cells were harvested at the time points $0 \mathrm{~h}, 3 \mathrm{~h}$, and $6 \mathrm{~h}$ and kept in lysis buffer at $-20^{\circ} \mathrm{C}$ for the next step. The total RNA was isolated from the cells using RNeasy mini kit (Qiagen) and 


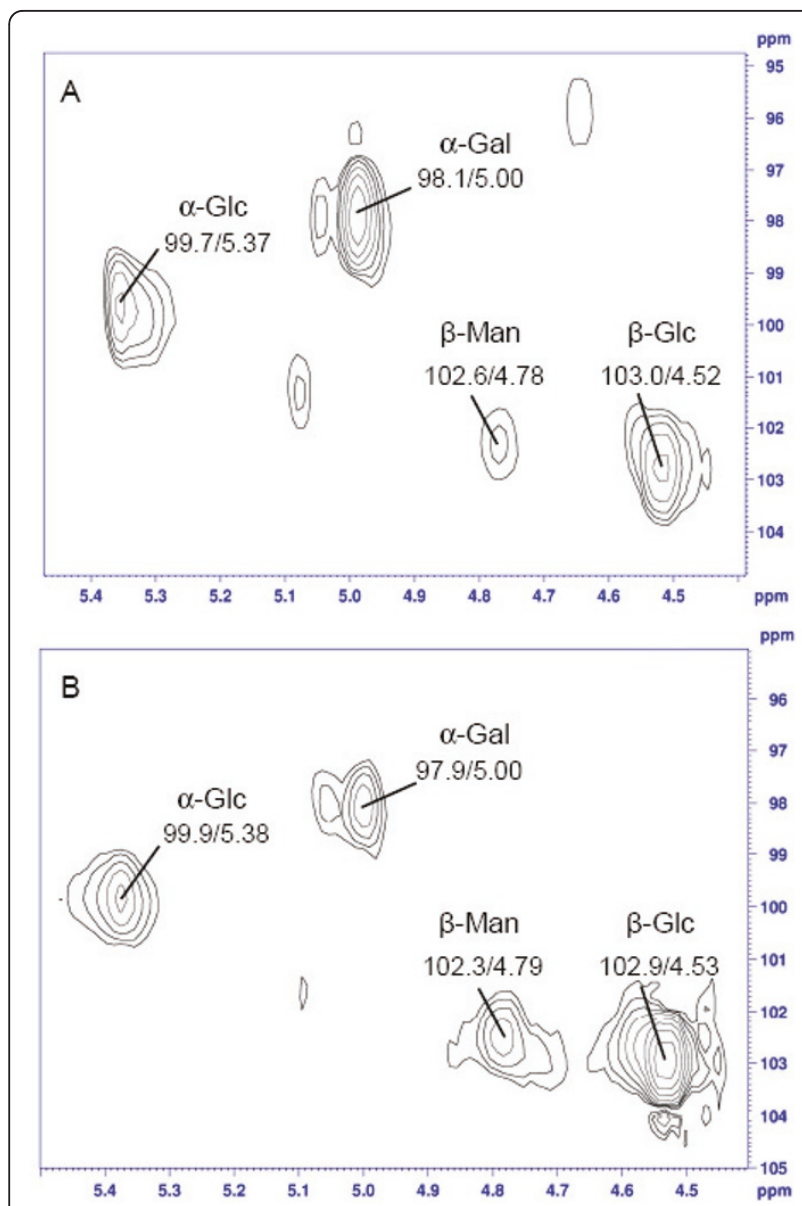

Figure 2 Anomeric regions of HSQC spectra from $A$. bisporus extract (ABS) (A) and A. blazei extract (ABL) (B).

$1 \mu \mathrm{g}$ was used to synthesize cDNA. The q-PCR analyses were pursued to evaluate the mRNA expression level of pro-inflammatory cytokine genes IL- $1 \beta$ and TNF- $\alpha$ and also the inflammation-related enzyme COX-2. Phosphate buffered saline (PBS; $50 \mu \mathrm{l}$ ) and lipopolysaccharide (LPS; $1 \mu \mathrm{g} / \mathrm{ml}$ ) were used as negative and positive controls, respectively. It was possible to observe that both crude extracts from $A$. bisporus and $A$. brasiliensis induced the expression of TNF- $\alpha$, IL- $1 \beta$, and COX-2 (Figure 3). TNF$\alpha$ showed a 150 fold increase of relative gene expression when compared to the time point $0 \mathrm{~h}$. This result was observed for both mushrooms after $3 \mathrm{~h}$ of incubation. After $6 \mathrm{~h}$ the level of mRNA started to decrease, which

Table 2 Proportions of polysaccharides in the extracts

\begin{tabular}{ccc}
\hline Polysaccharides & A. bisporus (\%) & A. brasiliensis (\%) \\
\hline$\alpha$-glucan & 20.4 & 25.7 \\
$\beta$-glucan & 23.7 & 49.1 \\
Mannogalactan & 55.8 & 25.2 \\
\hline
\end{tabular}
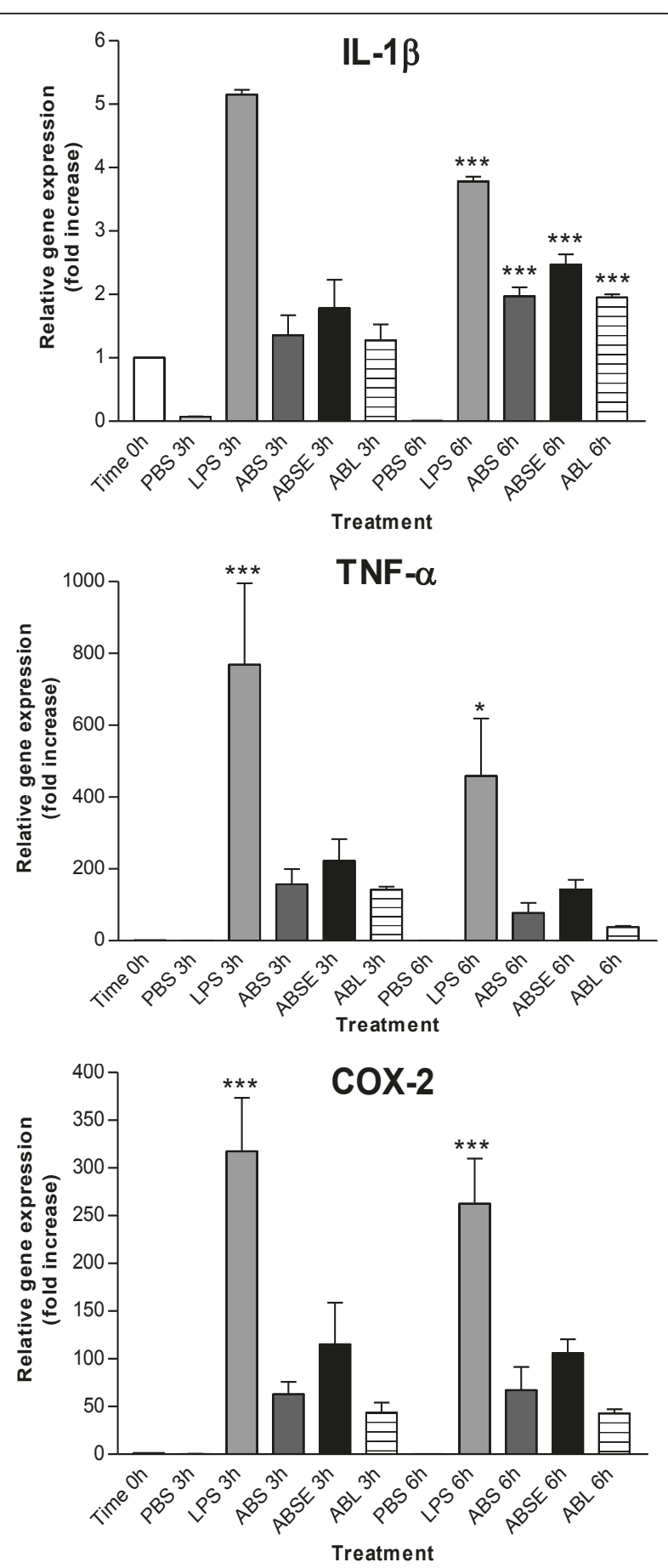

Figure 3 mRNA expression level of genes for IL-1 $\beta$, TNF- $\alpha$, and COX-2 after treatment with mushroom extracts. Negative control (PBS), positive control (LPS), A. bisporus extract (ABS), $\alpha-$ amylase treated $A$. bisporus extract (ABSE), and A. blazei extract (ABL). Statistical analyses were performed by means of one-way analysis of variance (ANOVA) followed by Bonferronis' test. The results represent the mean $\pm \mathrm{SD}$ of duplicate cultures of two representative experiments. ${ }^{*} p<0.05 ;{ }^{* *} p<0.01 ;{ }^{* * *} p<0.001$ versus negative control. 
was expected considering that this is the first cytokine to be produced under inflammatory stress [33,34]. IL-1 $\beta$ was expressed almost equally at both time points, ABS and ABL induced an almost 2-fold increase after $6 \mathrm{~h}$ treatment $(\mathrm{p}<0.001)$. The extract treated with $\alpha$-amylase showed higher stimulation compared to the others (2.5-fold increase; $\mathrm{p}<0.001)$. The presence of the $\alpha$-glucan interferes negatively with the activity; it probably blocks the active compounds or it interferes with their access to the membrane receptors, reducing cell stimulation and its effects.

Although the polysaccharides led to a high increase in production of TNF- $\alpha$, and COX-2 mRNAs, the effect observed for the positive control LPS was still higher than the other samples.

The ideal situation would keep a balance among proand anti-inflammatory cytokines. To evaluate if the A. brasiliensis extract (ABL) was able to diminish the levels of TNF- $\alpha$ and IL- $1 \beta$, we added the bacterial toxin LPS and ABL to the cells, in three different conditions, as described in table 3 . The aim was to verify if the mushroom extract could possibly reduce the pro-inflammatory cytokines produced in the presence of LPS, or if it increases the effect of lipopolysaccharide. After $9 \mathrm{~h}$ with LPS, the cells showed 3.9 and 9.4 fold increase for IL-1 $\beta$ and TNF- $\alpha$, respectively, compared to time $0 \mathrm{~h}$ (Figure 4). All conditions seemed to reduce the level of IL-1 $\beta$ induced by LPS stimulation, although the most effective was the simultaneous addition of ABL and LPS, which reduced the production of IL- $1 \beta$ in $56.5 \%$ ( $\mathrm{p}<0.001)$. While the most effective condition to modulate TNF- $\alpha$ was the simultaneous addition of both stimuli (reduction of 76.1\%; $\mathrm{p}<$ 0.01 ) or the addition of ABL after $3 \mathrm{~h}$ with LPS (reduction of $69.8 \%$; $<0.01)$.

\section{Discussion}

Basidiomycetes present different kinds of glucans and heteropolysaccharides. The common monosaccharide composition of these polymers is glucose, galactose, mannose, xylose, and fucose. Normally $(1 \rightarrow 3),(1 \rightarrow 6)-\beta$-glucans are extracted from these organisms, and also galactomannans, heteroglycans, and fucogalactans $[2,4]$. Mushrooms

Table 3 Description of conditions for treating cells

\begin{tabular}{|c|c|c|c|c|}
\hline Condition & Time $0 \mathrm{~h}$ & $\begin{array}{c}\text { After } 3 \\
\text { h }\end{array}$ & $\begin{array}{c}\text { After } 6 \\
\text { h }\end{array}$ & After $9 \mathrm{~h}$ \\
\hline Negative control & PBS & - & - & $\begin{array}{c}\text { All cells } \\
\text { were }\end{array}$ \\
\hline Positive control & LPS & - & - & harvested \\
\hline Stimulus at same time & $\begin{array}{c}\mathrm{LPS}+ \\
\mathrm{ABL}\end{array}$ & - & - & \\
\hline $\begin{array}{l}\text { Prevention with } \\
\text { extract }\end{array}$ & $A B L$ & - & LPS & \\
\hline Treatment with extract & LPS & $A B L$ & - & \\
\hline
\end{tabular}
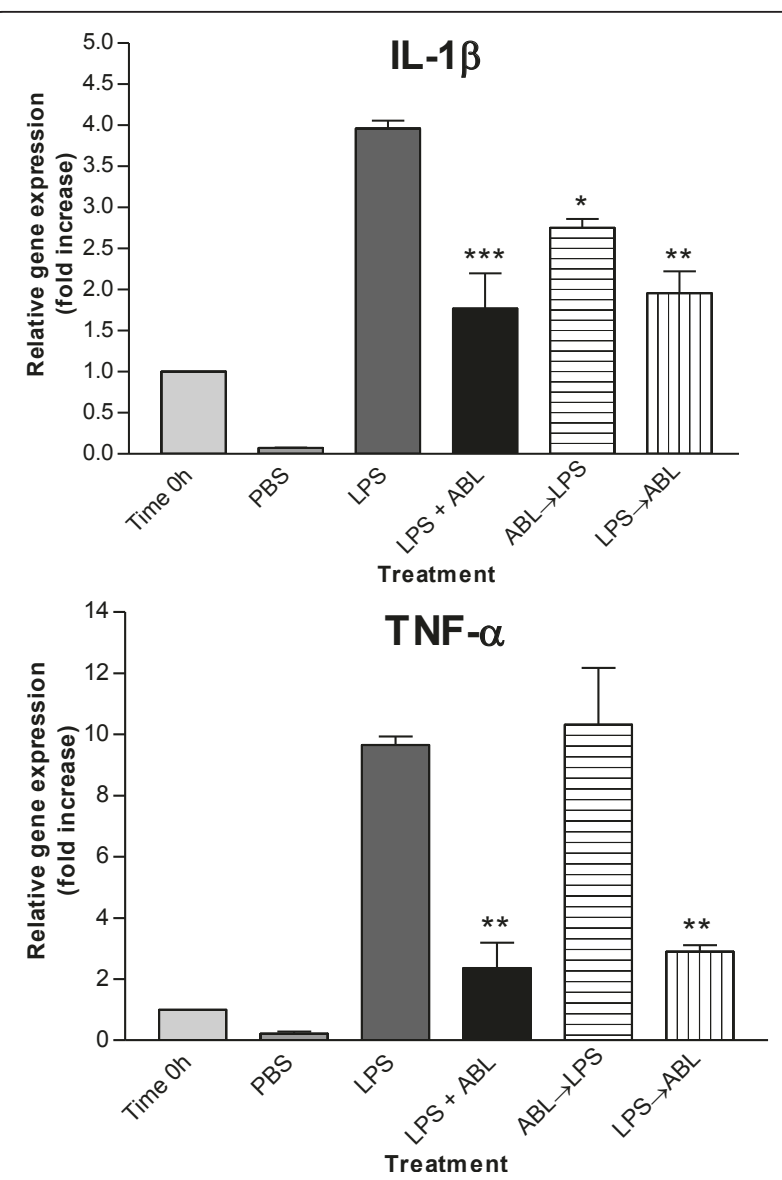

Figure 4 mRNA expression level of genes for IL-1 $\beta$, TNF- $\alpha$ after treatment with ABL. Negative control (PBS) and positive control (LPS). Statistical analyses were performed by means of one-way analysis of variance (ANOVA) followed by Bonferronis' test. The results represent the mean \pm SD of duplicate cultures of two representative experiments. ${ }^{*} p<0.05 ;{ }^{* *} p<0.01 ;{ }^{* * *} p<0.001$ versus positive control.

included in the same genera show more similarities in their composition, including the structure of carbohydrates [30]. In the present study, we compared two species from the genus Agaricus, which showed comparable NMR profiles. Both extracts contained mixtures of three main polysaccharides and their composition was comparable to what had been observed for other basidiomycete mushrooms, i.e. presenting glucose, galactose, mannose and fucose [16]. A. brasiliensis showed higher contents of $\beta$-glucan while $A$. bisporus presented mannogalactan as main polysaccharide. The proportion of each polysaccharide observed for both species varied significantly, and this may be an explanation for the differences encountered in the biological effects described by other authors. A. brasiliensis is known to be a medicinal mushroom and it has been widely used in Japan for many years for the treatment of cancer and other diseases [35]. A. bisporus, on the other hand, is mainly consumed as food; however 
there is quite some evidence concerning possible therapeutic properties as reduction of blood glucose [36] and cholesterol levels [37], generation of ROS species by human cells [26], and NO production stimulation [38].

In this study we evaluated the capacity of the mushroom extracts to stimulate the production of the proinflammatory cytokines TNF- $\alpha$, IL- $1 \beta$, and the enzyme COX-2 on THP-1 cells. In this assay, the samples were added to the cells and after different incubation periods they were harvested for analysis. The differences between both species were not significant. However a slight increase of expression was observed for the three transcripts induced by the $\alpha$-amylase treated polysaccharide (ABSE) of $A$. bisporus. This treatment increased the content of $\beta$-glucan and mannogalactan, since it degrades only $\alpha-(1 \rightarrow 4)$-linkages. Although this glycogen-like molecule showed antitumor properties [16], there are no reports showing an immunostimulatory activity. Galactomannan from $M$. esculenta [13] and a polysaccharide from G. lucidum, containing glucose (58.1\%), mannose (15.1\%), and galactose (13.5\%) had been found to stimulate THP-1 and showed an increase in NF- $\kappa$ B expression or were able to activate the differentiation to DC's, respectively [12]. Therefore, the presence of $\beta$-glucan may not be the only agent for the effects observed in the present study.

Macrophages contain specific membrane receptors that might bind polysaccharides and/or glycoproteins as Toll-like receptor 4 (TLR4), CD14, complement receptor 3 (CR3), scavenger receptor, dectin-1, and mannose receptor [4]. The binding to these receptors activates the transcription factor $\mathrm{NF}-\kappa \mathrm{B}$, which controls the expression of multiple genes in activated monocytes and macrophages. Some of the genes regulated by NF- $\kappa \mathrm{B}$ are the pro-inflammatory cytokines, chemokines, and inflammatory enzymes $[13,39]$. This could explain the induction of TNF- $\alpha$, IL- $1 \beta$, and COX- 2 by THP- 1 cells after the treatment with the extracts. It is known that the structure of the polysaccharides, as well as their conformation, molecular weight, and solubility in water may influence the receptor ligand interaction [2]. Moradali et al. (2007) [1] mentioned that triple-helix conformation of glucans and the presence of hydrophilic groups on the outside surface of the helix are important for their biological effect. Considering that the receptors are not specific for glucose polymers, it may be possible that the mannogalactan present in the extracts also bind the receptors, activating the nuclear transcription factor. Besides, the presence of the mannogalactan can also provide a well-suited conformation for the $\beta$-glucans, and facilitate their binding to dectin-1, the well-known receptor for glucans [39]. Further experiments should be performed to elucidate the mechanism of the immunomodulatory effects of these polymers.
A complementary study was performed to evaluate the capacity of ABL extract to reduce the expression of proinflammatory cytokines. The treatment reduced the expression of IL-1 $\beta$, and markedly reduced TNF- $\alpha$ production. The addition of ABL concomitantly with LPS or after $3 \mathrm{~h}$ was found to reduce or avoid the expression of TNF- $\alpha$ and IL- $1 \beta$, while the reduction, by adding ABL before LPS, was not effective. It was shown before that CD14 and Toll-like receptor 4 (TLR4) present in macrophages are essential for LPS recognition and consequently for responsiveness to this bacterial endotoxin [40]. Considering that these receptors are probably bound by polysaccharides, it is possible that there is competition between LPS and glucans/mannogalactans when added concomitantly. These experiments led to the conclusion that the semi-purified polysaccharide extracts of A. bisporus and A. brasiliensis can stimulate the production of pro-inflammatory cytokines and enzymes in THP-1 cells, as well as reduce the response to LPS.

It is well known that TNF- $\alpha$ and IL- $1 \beta$ are proinflammatory cytokines; therefore they can induce inflammation, fever and tissue damage. Blocking these chemokines could help relieve symptoms of inflammatory processes as in rheumatoid arthritis inflammatory bowel disease and other autoimmune diseases. Contrarily, as TNF- $\alpha$ and IL- $1 \beta$ play an important role against invasive pathogens, their induction may be relevant to increase e.g. antimicrobial resistance [41]. Eventual optimal application will depend on specifications of specific target groups.

The presence of $\alpha$-glucan in the A. bisporus extract reduced its activity, showing that the $\beta$-glucan and the mannogalactan are the major bioactive agents. In addition $A$. brasiliensis polysaccharide extract reduced the LPS induced synthesis of TNF- $\alpha$ and IL-1 $\beta$. Both extracts (ABS and $A B L$ ) presented comparable effects even though they showed significant differences in the proportion of $\beta$-glucan and mannogalactan in their composition. While A. bisporus presents $55.8 \%$ of mannogalactan and only $23.7 \%$ of $\beta$-glucan, $A$. brasiliensis is composed of $25.2 \%$ of mannogalactan and $49.1 \%$ of $\beta$-glucan.

\section{Conclusions}

The closely related species $A$. bisporus and $A$. brasiliensis show major differences in polysaccharide composition: $A$. bisporus shows high mannogalactan content whereas $A$. brasiliensis has mostly $\beta$-glucan. Semi-purified polysaccharide extracts from both Agaricus species stimulated the production of pro-inflammatory cytokines and enzymes, while the polysaccharide extract of $A$. brasiliensis reduced synthesis of these cytokines induced by LPS, suggesting programmable immunomodulation. 


\section{Acknowledgements and Funding}

The authors would like to thank the Brazilian funding agencies Conselho Nacional de Desenvolvimento Científico e Tecnológico (CNPq), Coordenação de Aperfeiçoamento de Pessoal de Nível Superior (CAPES), and Fundação Araucária.

\section{Author details}

'Plant Research International, Wageningen University and Research, Bornsesteeg 1, 6708 PD Wageningen, The Netherlands. ${ }^{2}$ Departamento de Bioquimica e Biologia Molecular, Universidade Federal do Paraná, Centro Politécnico, CP 19046, Curitiba-PR, Brasil. ${ }^{3}$ Wageningen University and Research Centre, Bornse Weilanden 9, 6708 WG Wageningen, The Netherlands.

\section{Authors' contributions}

FS carried out the chemical analyses and $\mathrm{QPCR}$, as well as the experiments with cells, and drafted the manuscript. AR participated on NMR experiments. JA carried out the HPLC analyses. WC participated in the design of the study with cells and the GPCR experiments. HW conceived of the study with cells and helped with discussion of results. Ml contributed with the discussion of chemical results and the design of chemical procedures. LG carried out the polysaccharide extractions, and coordinated the draft of the manuscript, helping with the discussion of biological results and English correction of the text. All authors read and approved the final manuscript.

\section{Competing interests}

The authors declare that they have no competing interests.

Received: 11 May 2011 Accepted: 25 July 2011 Published: 25 July 2011

\section{References}

1. Moradali MF, Mostafavi H, Ghods S, Hedjaroude GA: Immunomodulating and anticancer agents in the realm of macromycetes fungi (macrofungi). Int Immunopharmacol 2007, 7:701-724.

2. Zhang M, Cui SW, Cheung PCK, Wang Q: Antitumor polysaccharide from mushrooms: a review on their isolation process, structural characteristics and antitumor activity. Trends in Food Sci Technol 2007, 18:4-19.

3. Ramberg JE, Nelson ED, Sinnott RA: Immunomodulatory dietary polysaccharides: a systematic review of the literature. Nutr J 2010, 9(54):1-22.

4. Schepetkin IA, Quinn MT: Botanical polysaccharides: Macrophage immunomodulation and therapeutic potential. Int Immunopharmacol 2006, 6:317-333.

5. Mosser DM, Edwards JP: Exploring the full spectrum of macrophage activation. Nat Rev Immunol 2008, 8:958-969.

6. Thompson IJ, Oyston PCF, Williamson DE: Potential of the $\beta$-glucans to enhance innate resistance to biological agents. Expert Rev Anti Infect Ther 2010, 8(3):339-352

7. Lull C, Wichers HJ, Savelkoul HFJ: Antiinflammatory and immunomodulating properties of fungal metabolites. Med Inflammation 2005, 2:63-80.

8. Tsuchiya S, Yamabe M, Yamaguchi Y, Kobayashi Y, Konno T, Tada K: Establishment and characterization of a human acute monocytic leukemia cell line (THP-1). Int J Cancer 1980, 26:171-176.

9. Kohro T, Tanaka T, Murakami T, Wada Y, Aburatani H, Hamakubo T, Kodama T: A comparison of differences in the gene expression profiles of phorbol-12-myristate 13-acetate differentiated THP-1 cells and human monocytederived macrophage. J Atheroscl Thromb 2004, 11:88-97.

10. Daigneault M, Preston JA, Marriott HM, Whyte MKB, Dockrell DH: The identification of markers of macrophage differentiation in PMAstimulated THP-1 cells and monocyte-derived macrophages. Plosone 2010, 5(1):1-10.

11. Chan WK, Cheung CCH, Law HKW, Lau YL, Chan GCF: Ganoderma lucidum polysaccharides can induce human monocytic leukemia cells into dendritic cells with immuno-stimulatory function. $J$ Hematol Oncol 2008, 1-9.

12. Hsu JW, Huang HC, Chen ST, Wong CH, Juan HF: Ganoderma lucidum polysaccharides induce macrophage-like differentiation in human leukemia THP-1 cells via caspase and p53 activation. Evidence-Based Comp Alternat Med 2011, 1-13.
13. Duncan CJG, Pugh N, Pasco DS, Ross SA: Isolation of a galactomannan that enhances macrophage activation from the edible fungus Morchella esculenta. J Agric food chem 2002, 50:5683-5685.

14. Sakagami Y, Mizoguchi Y, Shin T, Seki S, Kobayashi K, Morisawa S, Yamamoto S: Effects of an anti-tumor polysaccharide, schizophyllan, on interferon- $\gamma$ and interleukin 2 production by peripheral blood mononuclear cells. Biochem Biophys Res Comm 1988, 155:650-655.

15. Rubin-Bejerano I, Abeijon C, Magnelli P, Grisafi P, Fink GR: Phagocytosis by human neutrophils is stimulated by a unique fungal cell wall component. Cell Host Microb 2007, 2:55-67.

16. Mizuno T, Hagiwara T, Nakamura T, Ito H, Shimura K, Sumiya T, Asakura A: Antitumor activity and some properties of water-soluble polysaccharides from "Himematsutake", from the fruiting body of Agaricus blazei Murill. Agric Biol Chem 1990, 54(11):2889-2896.

17. Ito $H$, Shimura $K$, Itoh $H$, Kawade M: Antitumor effects of a new polysaccharide-protein complex (ATOM) prepared from Agaricus blazei (Iwade strain 101) "Himematsutake" and its mechanisms in tumorbearing mice. Anticancer Res 1997, 17(1A):277-84.

18. Gonzaga MLC, Ricardo NMPS, Heatley F, Soares SA: Isolation and characterization of polysaccharides from Agaricus blazei Murill. Carbohydr Polym 2005, 60:43-49.

19. Chanput W, Mes J, Vreeburg RAM, Savelkoul HFJ, Wichers HJ: Transcription profiles of LPS-stimulated THP-1 monocytes and macrophages: a tool to study inflammation modulating effects of food-derived compounds. Food Funct 2010, 1:254-261.

20. Livak KJ, Schmittgen TD: Analysis of relative gene expression data using realtime quantitative PCR and the $2^{-\Delta \Delta C}$ T method. Methods 2001, 25:402-408.

21. Wei S, Van Griensven LJLD: Pro- and antioxidative properties of medicinal mushroom extracts. Int J Med Mushr 2008, 10(4):315-324.

22. Sassaki GL, Souza LM, Serrato RV, Cipriani TR, Gorin PAJ, lacomini M: Application of acetates derivatives for gas chromatography-mass spectrometry: Novel approaches on carbohydrates, lipids and amino acids analysis. J Chromatogr A 2008, 1208:215-222.

23. Sassaki GL, Gorin PAJ, Souza LM, Czelusniak PA, lacomini M: Rapid synthesis of partially O-methylated alditol acetate standards for GC-MS some relative activities of hydroxyl groups of methyl glycopyranosides on Purdie methylation. Carbohydr Res 2005, 340:731-739.

24. Smiderle FR, Sassaki GL, van Arkel J, lacomini M, Wichers HJ, van Griensven JLD: High molecular weight glucan of the culinary medicinal mushroom Agaricus bisporus is an a-glucan that forms complexes with low molecular weight galactan. Molecules 2010, 15:5818-5830.

25. Ainsworth EA, Gillespie KM: Estimation of total phenolic content and other oxidation substrates in plant tissues using Folin-Ciocalteu reagent. Nat Protocols 2007, 2:4, 875-877.

26. Wei S, Helsper JPFG, Van Griensven LJLD: Phenolic compounds present in medicinal mushroom extracts generate reactive oxygen species in human cells in vitro. Int J Med Mushr 2008, 10(1):1-13.

27. Renard CMCG, Baron A, Guyot S, Drilleau JF: Interactions between apple cell walls and native apple polyphenols quantification and some consequences. Int J Biol Macromol 2001, 29:115-25.

28. Jakovljevic D, Miljkovic-Stojanovic J, Radulovic M, HranisavljevicJakovljevic M: On the mannogalactan from the fruit bodies of Pleurotus ostreatus (Fr.) Quél. J Serb Chem Soc 1998, 63(2):137-142.

29. Smiderle FR, Olsen LM, Carbonero ER, Marcon R, Baggio C, Freitas C, Santos ARS, Torri G, Gorin PAJ, lacomini M: A 3-O-methylated mannogalactan from Pleurotus pulmonarius: Structure and antinociceptive effect. Phytochem 2008, 69(15):2731-2736.

30. Carbonero ER, Gracher AHP, Rosa MCC, Torri G, Sassaki GL, Gorin PAJ, lacomini M: Unusual partially 3-O-methylated a-galactan from mushrooms of the genus Pleurotus. Phytochem 2008, 69:252-257.

31. Schlesinger LS, Hull SR, Kaufman TM: Binding of terminal mannosyl units of lipoarabinomannan from a virulent strain of Mycobacterium tuberculosis to human macrophages. J Immunol 1994, 152(8):4070-4079.

32. Mizuno T, Inagaki R, Kanao T, Hagiwara T, Nakamura T, Ito H, Shimura K, Sumiya T, Asakura A: Antitumor activity and some properties of waterinsoluble hetero-glycans from "Himematsutake", the fruiting body of Agaricus blazei Murill. Agric Biol Chem 1990, 54(11):2897-2905.

33. Armstrong $L$, Jordan $N$, Millar A: Interleukin 10 (IL-1) regulation of tumour necrosis factor $\mathrm{Cx}$ (TNF-CX) from human alveolar macrophages and peripheral blood monocytes. Thorax 1996, 51:143-149. 
34. Sato TA, Keelan JA, Mitchell MD: Critical paracrine interactions between TNF- $a$ and IL-10 regulate lipopolysaccharide-stimulated human chloriodecidual cytokine and prostaglandin E2 production. J Immunol 2003, 170:158-166

35. Camelini CM, Maraschin M, Mendonc MM, Zucco C, Ferreira AG, Tavares LA: Structural characterization of $\beta$-glucans of Agaricus brasiliensis in different stages of fruiting body maturity and their use in nutraceutical products. Biotechnol Lett 2005, 27:1295-1299.

36. Yamac M, Kanbak G, Zeytinoglu M, Senturk H, Bayramoglu G, Dokumacioglu A, Van Griensven LLD: Pancreas protective effect of antioxidative Agaricus bisporus extract on rats with streptozotocin induced diabetes. Int J Med Mushr 2010, 12(4):379-389.

37. Jeong SC, Jeong YT, Yang BK, Islam R, Koyyalamudi SR, Pang G, Cho KY, Song $\mathrm{CH}$ : White button mushroom (Agaricus bisporus) lowers blood glucose and cholesterol levels in diabetic and hypercholesterolemic rats. Nutr Res 2010, 30:49-56.

38. Volman JJ, Helsper JPFG, Wei S, Baars JJP, Van Griensven LJLD, Sonnenberg ASM, Mensink RP, Plat J: Effects of mushroom-derived bglucan-rich polysaccharide extracts on nitric oxide production by bone marrow-derived macrophages and nuclear factor-jB transactivation in Caco-2 reporter cells: Can effects be explained by structure? Mol Nutr Food Res 2010, 54:268-276.

39. Tada R, Ikeda F, Aoki K, Yoshikawa M, Kato Y, Adachi Y, Tanioka A, Ishibashi K, Tsubaki K, Ohno N: Barley-derived $\beta$-D-glucan induces immunostimulation via a dectin-1-mediated pathway. Immunol Lett 2009, 123:144-148.

40. Fujuhara M, Muroi M, Tanamoto K, Suzuki T, Azuma H, Ikeda H: Molecular mechanisms of macrophage activation and deactivation by lipopolysaccharide: roles of the receptor complex. Pharmacol Ther 2003, 100:171-194.

41. Dinarello CA: Proinflammatory cytokines. Chest 2000, 118:503-508.

\section{Pre-publication history}

The pre-publication history for this paper can be accessed here: http://www.biomedcentral.com/1472-6882/11/58/prepub

\section{doi:10.1186/1472-6882-11-58}

Cite this article as: Smiderle et al:: Polysaccharides from Agaricus bisporus and Agaricus brasiliensis show similarities in their structures and their immunomodulatory effects on human monocytic THP-1 cells. BMC Complementary and Alternative Medicine 2011 11:58.

\section{Submit your next manuscript to BioMed Central and take full advantage of:}

- Convenient online submission

- Thorough peer review

- No space constraints or color figure charges

- Immediate publication on acceptance

- Inclusion in PubMed, CAS, Scopus and Google Scholar

- Research which is freely available for redistribution

Submit your manuscript at www.biomedcentral.com/submit 